\author{
M.K. Butumbayeva*, M.M. Silant'eva \\ Altai State University, Barnaul, Russia \\ *Corresponding author: madina_butumbaeva@mail.ru
}

\title{
Evaluation of successful introduction of plants from Lamiaceae family in the conditions of the Karaganda and Zhezkazgan cities
}

\begin{abstract}
Evaluation of the success of plant introduction is an important stage of determining the possibility of industrial cultivation of individual taxa from an economic point of species. The success of the introduction is assessed on the basis of multi-year observations based on the evaluation of a number of indicators. The purpose of this study is to analyze the success of the introduction of species from the Lamiaceae family in the conditions of the cities of Karaganda and Zhezkazgan. The article presents the results of the assessment of the success of the introduction of plants of the Lamiaceae family on the territory of the cities of Karaganda (E.A. Buketov Karaganda University) and Zhezkazgan (Zhezkazgan Botanical Garden). In the city of Karaganda, 20 species from 13 genera were analyzed, in the city of Zhezkazgan - 14 species from 9 genera. Promising groups have been identified that allow recommending plants for industrial cultivation. In the conditions of the city of Karaganda, 6 species are classified as highly perspective, 4 species are perspective, 8 species are low perspective, and 2 species are not perspective. In the city of Zhezkazgan, 2 species are highly perspective, 3 species are perspective, 4 species are low perspective, and 5 species are not perspective. Plants suitable for cultivation in the conditions of the city of Karaganda and Zhezkazgan have been identified. The obtained results can be used for production of raw materials for food, aromatic and pharmaceutical industries.
\end{abstract}

Keywords: success of introduction, Lamiaceae family, Karaganda, Zhezkazgan, scoring points, possibility of industrial cultivation.

\section{Introduction}

The introduction of plants is one of the initial stages of the cultivation of plants in order to verify the possibility of their growth under certain soil and climatic conditions, as well as for industrial production of raw materials.

Usually, introductory research is carried out in botanical gardens of various levels and botanical organizations [1]. As a result of the introduction into the culture, the question arises of assessing the success of their introduction [2], that is, the isolation of objects suitable for further cultivation and practical using.

Representatives of the Lamiaceae Lindl. family today are species of flora with a fairly large content of biologically active substances (aromatic, phenolic, lipid, steroid compounds, resins, organic and mineral substances), widely used in official and folk medicine. Organs and herbs of plants of this family are raw materials for pharmaceutical, food, cosmetic, technical and many other industries [3-11].

In Kazakhstan, this family is represented by 233 species, united in 45 genera [12]. Species of Lamiaceae participate in the formation of various types of plant communities, are harvested as essential and medicinal plants, are used as excellent meadow, ornamental and fodder plants [5].

Earlier, in the territory of the Karaganda region, a primary assessment of the distribution of wild species of the Lamiaceae was carried out, maps of ranges [13] were compiled; resources of some species were determined [14]. So, out of 50 identified species, 43 species were assigned to essential-oil plants, to medicines - 32 species, to honey -47 species, to feed -28 species, to technical -6 species, food 7 species, decorative - 18 species and vitamin -5 species [15].

There is information on the introduction of certain species [16], however, the introductive potential of all representatives has not been practically investigated. Evaluation of the success of plant introduction allows you to choose the species that can be successfully grown in the conditions of the Central Kazakhstan, to be used as a source of raw materials for various industries.

Based on the above, the purpose of this study is to assess the success of the introduction of plants from the Lamiaceae family in the conditions of the Central Kazakhstan (the cities of Karaganda and Zhezkazgan). 


\section{Materials and methods}

The object of the study was the collections of natural flora and medicinal plants of E.A. Karaganda Karaganda University and the Zhezkazgan Botanical Garden. The data analysis covered the period of observations of collectible plants of the Lamiaceae family from 1998 to 2018.

The success assessment of the introduction of medicinal plants was carried out according to visual observations on a 100-point scale developed by R.A. Karpisonova and supplemented by A.N. Kupriyanov (2004) $[17,18]$. Such indicators as winter resistance, resistance to diseases and pests, the general state of plants, methods of reproduction in culture, the general state of plants during the growing season were evaluated.

Species with 90 to 100 points were classified as highly perspective plants for a given region; from 80 to 90 points - to perspective; from 60 to 80 points - to low perspective; below 60 points - to not perspective (Table 1).

Table 1

Evaluation of introduction success indicators based on visual observations

\begin{tabular}{|c|c|c|c|c|c|c|}
\hline \multirow{2}{*}{ Parameters } & \multirow{2}{*}{$\begin{array}{c}\text { Measure } \\
\text { Evaluation Time }\end{array}$} & \multicolumn{5}{|c|}{ Points } \\
\hline & & 0 & 5 & 10 & 15 & 20 \\
\hline Winter resistant & $\begin{array}{l}\text { In spring, after } \\
\text { growing plants }\end{array}$ & $\begin{array}{l}\text { completely } \\
\text { freeze after } \\
\text { winter }\end{array}$ & $\begin{array}{c}\text { more than } 50 \% \\
\text { of individuals } \\
\text { freeze }\end{array}$ & $\begin{array}{l}30-50 \% \text { of } \\
\text { individuals } \\
\text { freeze out }\end{array}$ & $\begin{array}{l}\text { less than } 30 \% \text { of } \\
\text { individuals freeze }\end{array}$ & $\begin{array}{l}\text { plants without } \\
\text { winter damage }\end{array}$ \\
\hline $\begin{array}{l}\text { Resistance to } \\
\text { diseases and } \\
\text { pests }\end{array}$ & $\begin{array}{l}\text { During plant } \\
\text { flowering }\end{array}$ & $\begin{array}{l}\text { die due to } \\
\text { pests or dis- } \\
\text { eases influ- } \\
\text { ence }\end{array}$ & \begin{tabular}{|c|}
$\begin{array}{c}\text { It is damaged } \\
\text { annually and } \\
\text { abundantly } \\
\text { (more than } 50 \% \\
\text { of the sheet sur- } \\
\text { face is dam- } \\
\text { aged) }\end{array}$ \\
\end{tabular} & $\begin{array}{r}\text { damage severe, } \\
\text { but not annual } \\
\end{array}$ & $\begin{array}{c}\text { annual or non- } \\
\text { annual non-severe } \\
\text { damage (less than } \\
50 \% \text { damage) }\end{array}$ & $\begin{array}{c}\text { plants without } \\
\text { damage }\end{array}$ \\
\hline $\begin{array}{l}\text { The general state } \\
\text { of plants }\end{array}$ & $\begin{array}{l}\text { Towards the end } \\
\text { of the growing } \\
\text { season }\end{array}$ & - & $\begin{array}{l}\text { low-power } \\
\text { plants that do } \\
\text { not reach their } \\
\text { natural size in } \\
\text { culture }\end{array}$ & - & $\begin{array}{c}\text { do not differ in } \\
\text { size from plants } \\
\text { in natural habitats }\end{array}$ & $\begin{array}{c}\text { plants are more } \\
\text { powerful than } \\
\text { in nature }\end{array}$ \\
\hline $\begin{array}{l}\text { Methods of re- } \\
\text { production in } \\
\text { culture }\end{array}$ & $\begin{array}{c}\text { Towards the end } \\
\text { of the growing } \\
\text { season }\end{array}$ & - & $\begin{array}{c}\text { grow, but do not } \\
\text { flower or form } \\
\text { seeds }\end{array}$ & $\begin{array}{l}\text { bloom, but do } \\
\text { not bear fruit }\end{array}$ & $\begin{array}{c}\text { seed ratio small or } \\
\text { not annual }\end{array}$ & $\begin{array}{l}\text { annually } \\
\text { bloom and } \\
\text { form seeds }\end{array}$ \\
\hline $\begin{array}{l}\text { The general state } \\
\text { of plants during } \\
\text { the growing sea- } \\
\text { son }\end{array}$ & $\begin{array}{c}\text { Based on the } \\
\text { results of many } \\
\text { years of observa- } \\
\text { tions }\end{array}$ & - & $\begin{array}{l}\text { re-engagement } \\
\text { in culture }\end{array}$ & $\begin{array}{c}\text { artificial } \\
\text { vegetative } \\
\text { reproduction }\end{array}$ & $\begin{array}{c}\text { natural vegetative } \\
\text { reproduction }\end{array}$ & $\begin{array}{l}\text { subsequent } \\
\text { reproduction }\end{array}$ \\
\hline
\end{tabular}

\section{Results and discussion}

The points of introduction - Karaganda and Zhezkazgan differ significantly in the complex of soilclimatic conditions [19]. So, Karaganda is located in the steppe zone. The climate is continental with a temperature difference from 20 to $40^{\circ} \mathrm{C}$. The winter period lasts from mid-late October to April. The average length of the warm season is $180-195$ days; the average January temperature is $-15.1^{\circ} \mathrm{C}$ (Table 2), July $+20.2^{\circ} \mathrm{C}$. Maximum positive temperatures up to $+45-47^{\circ} \mathrm{C}$, in some years there were decreases in temperatures up to $+42{ }^{\circ} \mathrm{C}$. A stable snow cover forms in the 1 st-2nd decades of November and lasts until midMarch. The depth of snow cover is from 30 to $120 \mathrm{~cm}$. 
Table 2

Main climatic indicators of Karaganda and Zhezkazgan

\begin{tabular}{|c|c|c|c|c|c|c|}
\hline \multirow{3}{*}{ Month } & \multicolumn{6}{|c|}{ Indicator } \\
\hline & \multicolumn{2}{|c|}{ Average air temperature, ${ }^{\circ} \mathrm{C}$} & \multicolumn{2}{|c|}{ Relative air humidity, $\%$} & \multicolumn{2}{|c|}{ Precipitation, $\mathrm{mm}$} \\
\hline & Karaganda & Zhezkazgan & Karaganda & Zhezkazgan & Karaganda & Zhezkazgan \\
\hline January & -15.1 & -16.1 & 60 & 80 & 14 & 23 \\
\hline February & -14.8 & -14.6 & 80 & 80 & 14 & 22 \\
\hline March & -8.7 & 7.2 & 82 & 80 & 15 & 23 \\
\hline April & 3.0 & 6.2 & 68 & 61 & 22 & 17 \\
\hline May & 13.1 & 15.5 & 55 & 47 & 31 & 13 \\
\hline June & 18.6 & 21.5 & 53 & 42 & 39 & 20 \\
\hline July & 20.2 & 24.0 & 55 & 40 & 41 & 18 \\
\hline August & 17.3 & 21.2 & 58 & 42 & 29 & 13 \\
\hline September & 11.8 & 14.4 & 70 & 47 & 21 & 10 \\
\hline October & 2.8 & 4.8 & 80 & 61 & 27 & 15 \\
\hline November & -6.8 & -5.1 & 80 & 78 & 17 & 14 \\
\hline December & -13.3 & -12.0 & 82 & 80 & 16 & 20 \\
\hline Average per year & 2.3 & 4.3 & 66 & 62 & 282 & 208 \\
\hline
\end{tabular}

Zhezkazgan city is located in the desert zone. The climate is sharply continental, strongly arid, temperature differences reach $50-60^{\circ} \mathrm{C}$. The winter period lasts from early November to early March. The average January temperature is $-16.1{ }^{\circ} \mathrm{C}$; for July is $+24.0^{\circ} \mathrm{C}$. A stable snow cover is formed in late November early December and remains until the 1st-2nd decades of March. That is, the growing season is longer, but less precipitation.

Under the conditions of Karaganda, 20 species of plants from the Lamiaceae family [20], which belong to 13 genera, underwent an introduction test (Table 3).

T a b l e 3

Indicators of the success of the introduction of plants of the Lamiaceae family in the conditions of Karaganda

\begin{tabular}{|c|c|c|}
\hline Genus & Species & $\begin{array}{c}\text { Introduction Success } \\
\text { Rates, Points }\end{array}$ \\
\hline \multirow{2}{*}{ Hyssopus L. } & H.ambiguus (Trautv.) Iljin & 95 \\
\hline & H. officinalis $\mathrm{L}$. & 90 \\
\hline Lavandula $\mathrm{L}$. & L.angustifolia Mill. & 90 \\
\hline \multirow{3}{*}{ Leonurus L. } & L.cardiaca $\mathrm{L}$. & 100 \\
\hline & L. glaucescens Bunge & 95 \\
\hline & L.quinquelobatus Gilib. & 95 \\
\hline Lophanthus Adans. & L.schrenkii Levin & 50 \\
\hline Melissa $\mathrm{L}$. & M.officinalis L. & 80 \\
\hline \multirow{3}{*}{ Mentha L. } & M.arvensis L. & 75 \\
\hline & M.longifolia (L.) Huds. & 80 \\
\hline & M.piperita L. & 65 \\
\hline Nepeta L. & N.pannonica L. & 85 \\
\hline Origanum L. & O.vulgare L. & 75 \\
\hline Phlomoides Moench & Ph. tuberosa (L.) Moench & 90 \\
\hline \multirow{2}{*}{ Salvia L. } & S. officinalis L. & 50 \\
\hline & S. stepposa Shost. & 95 \\
\hline Stachys L. & S. officinalis L. & 80 \\
\hline \multirow{2}{*}{ Thymus L. } & Th.marschallianus Willd. & 95 \\
\hline & Th.serpyllum L. & 80 \\
\hline Ziziphora L. & Z. clinopodioides Lam. & 90 \\
\hline
\end{tabular}

According to the results of long-term observations, species received from 50 to 100 rating points for the success of introduction. The highest score (100 points) was for Leonurus cardiaca, the minimum (50 points) for Salvia officinalis. The last object received low scores due to extinction in winter. The remaining species practically did not suffer from winter conditions. 
In general, most species received scores from 80 to 95 points, that is, they successfully grow under crop conditions, are resistant to winter conditions, pathogens and can successfully reproduce.

In the city of Zhezkazgan, 14 species from 9 genera underwent an introduction test (Table 4).

Table 4

\section{Indicators of the success of the introduction of plants of the Lamiaceae family in the conditions of Zhezkazgan}

\begin{tabular}{|l|l|c|}
\hline \multicolumn{1}{|c|}{ Genus } & \multicolumn{1}{|c|}{ Species } & $\begin{array}{c}\text { Introduction Success } \\
\text { Rates, Points }\end{array}$ \\
\hline Hyssopus L. & H. officinalis L. & 90 \\
\hline Leonurus L. & L. glaucescens Bunge & 100 \\
\hline Melissa L. & M. officinalis L. & 55 \\
\hline \multirow{2}{*}{ Mentha L. } & M. longifolia (L.) Huds. & 80 \\
\cline { 2 - 3 } & M. piperita L. & 60 \\
\hline Phlomoides Moench & Ph. tuberosa L.) Moench & 95 \\
\hline \multirow{5}{*}{ Salvia L. } & S. aethiopsis L. & 25 \\
\cline { 2 - 3 } & S. officinalis L. & 25 \\
\cline { 2 - 3 } & S. sclarea L. & 55 \\
\cline { 2 - 3 } Scutellaria L. & S. stepposa Shost. & 90 \\
\hline \multirow{2}{*}{ Stachys L. } & S. baicalensis Georgi & 55 \\
\hline Thymus L. & S. betoniciflora Rupr. & 90 \\
\cline { 2 - 3 } & S. officinalis L. & 65 \\
\hline
\end{tabular}

In desert conditions of Zhezkazgan, 5 species received low success scores, minimum ( 25 points) were noted for Salvia aethiopsis and S. officinalis, maximum (100 points) - Leonurus glaucescens. The current situation is explained by the fact that on the territory of the city of Zhezkazgan more severe climatic conditions are observed [19], which leads to low indicators of plant introduction.

The results showed that in the conditions of the city of Karaganda:

-6 species are assigned to the group of highly perspective species (Hyssopus ambiguus, Leonurus glaucescens, L.cardiaca, etc.);

- 4 species are assigned to perspective species (Hyssopus officinalis, Nepeta pannonica, Phlomoides tuberosa, Ziziphora clinopodioides);

- low perspective species include 8 species (Thymus serpyllum, Stachys officinalis, Mentha longifolia, M.arvensis, Origanum vulgare, etc.);

- not perspective - 2 (Lophanthus schrenkii and Salvia officinalis).

In the city of Zhezkazgan:

- 2 taxa are assigned to highly perspective species (Leonurus glaucescens and Phlomoides tuberosa);

- perspective species - 3 (Hyssopus officinalis, Salvia stepposa, Stachys betoniciflora);

- low perspective species - 4 (Mentha longifolia, Mentha piperita, Stachys officinalis, Thymus marschallianus);

- the remaining species belong to the group of not perspective -5 taxa.

Species included in the group of highly promising and promising can be used for industrial cultivation in order to obtain raw materials.

\section{Conclusion}

Thus, according to the results of research, the results of the successful introduction of plants of the Lamiaceae family in the conditions of the Central Kazakhstan were determined; taxa that can be grown on an industrial scale were determined. The obtained results can be used to organize industrial cultivation of plants for the needs of the food, pharmaceutical and aromatic industries.

\section{Acknowledgements}

The article has been prepared as a part of complex survey of river valleys of the Karaganda region (the Central Kazakhstan) carried out within the framework of cooperation between E.A. Buketov Karaganda University and Altai State University (Barnaul). 


\section{References}

1 Карпун Ю.Н. Основы интродукции растений / Ю.Н. Карпун // Hortus botanicus. — 2004. — № 2. — C. 17-32.

2 Крохмаль И. Концепция прогноза успешности интродукции травянистых многолетников в степную зону Украины / И. Крохмаль // Вестн. Киев. нац. ун-та им. Т. Шевченко. — 2016. — № 1(71). — С. 66-77.

3 Абышева Л.Н. Дикорастущие полезные растения России / Л.Н. Абышева, Л.М. Беленовская, Н.С. Бобылева. - СПб.: Изд-во СПХФА, 2001. - 663 с.

4 Мяделенец М.А. Губоцветные Хакасии: видовой состав, экология и перспективы использования: автореф. дис. ... канд. биол. наук / М.А. Мяделянец. — Новосибирск, 2008. - 17 с.

5 Грудзинская Л.М. Аннотированный список лекарственных растений Казахстана: справ. изд. / Л.Н. Грудзинская, Н.Г. Гемеджиева, Н.В. Нелина, Ж.Ж. Каржаубекова. — Алматы, 2014. — 200 с.

6 Логвиненко Л.А. Ароматические растения семейства Lamiaceae для фитотерапии / Л.А. Логвиненко, Л.А. Хлыпенко, Н.В. Марко // Фармация и фармакология. — 2016. — Т. 4, № 4. — С. 34-47. https://doi.org/10.19163/2307-9266-2016-4-4-3447

7 Khoury M. Report on the Medicinal Use of Eleven Lamiaceae Species in Lebanon and Rationalization of Their Antimicrobial Potential by Examination of the Chemical Composition and Antimicrobial Activity of Their Essential Oils / M. Khoury, D. Stien, V. Eparvier, N. Ouaini, M. El Beyrouthy // Hindawi. — 2016. — Article ID 2547169. https://doi.org/10.1155/2016/2547169

8 Blank D.E. Chemistry and Environment Bioactive Compounds and Antifungal Activities of Extracts of Lamiaceae Species / D.E. Blank, G.H. Alves, P. Da, S. Nascente, R.A. Freitag, M.B. Cleff // Journal of Agricultural Chemistry and Environment. 2020. - Vol. 9. - P. 85-96. https://doi.org/10.4236/jacen.2020.93008

9 Carović-Stanko K. Medicinal Plants of the Family Lamiaceae as Functional Foods - a Review / K. Carović-Stanko, M. Petek, M. Grdiša, J. Pintar, D. Bedeković, M.H. Custić, Z. Satovic // Czech J. Food Sci. — 2016. — Vol. 34, Iss. 5. — P. $377-$ 390. https://doi.org/10.17221/504/2015-CJFS

10 Звездина Е.В. Представители семейства Lamiaceae Lindl. как источники лекарственного растительного сырья для получения нейротропных средств (обзор) / Е.В. Звездина, Ж.В. Дайронас, И.И. Бочкарева, И.Н. Зилфикаров, Е.Ю. Бабаева, Е.В. Ферубко, З.А. Гусейнова, Ф.К. Серебряная, С.Р. Каибова, Т.А. Ибрагимов // Фармация и фармакология. - 2020. T. 8, № 1. - C. 4-28.

11 Rafiyeva S. Essential oil features of some species of Lamiaceae Lindl. Family / S. Rafiyeva // Black sea scientific journal of academic research. - 2019. - Vol. 46, Iss. 3. - P. 30-33.

12 Флора Казахстана. - Т. 7. - Алма-Ата: Изд-во АН КазССР, 1964. — 495 с.

13 Ишмуратова М.Ю. Изучение распространения растений семейства Губоцветные на территории Карагандинской области / М.Ю. Ишмуратова, М.К. Бутумбаева, К.Б. Жолдыбаева // Методология, теория и практика современной биологии: Сб. материалов V Междунар. науч.-практ. конф. - Костанай, 2020. — С. 171-176.

14 Akhmetalimova A.M. Study of raw material resources of Thymus marschallianus at the territory of the Central Kazakhstan / A.M. Akhmetalimova, P.Z. Orazbayeva, M.Yu. Ishmuratova, S.A. Ivasenko, K. Glowniak // Bulletin of the Karaganda University. Series Biology. Medicine. Geography. - 2017. - No. 4. - P. 8-13.

15 Бутумбаева М.К. Оценка хозяйственных свойств видов из семейства Губоцветные флоры Карагандинской области / М.К. Бутумбаева, М.Ю. Ишмуратова, С.У. Тлеукенова // Актуальные проблемы науки и образования в области естественных и сельскохозяйственных наук: материалы Междунар. науч.-практ. конф. - Петропавловск, 2020. — Т. 1. — С. 74-77.

16 Ишмуратова М.Ю. Интродукция Ziziphora clinopodioides Lam. в условиях Центрального Казахстана / М.Ю. Ишмуратова // Вестн. Караганд. ун-та. Сер. Биология. Медицина. География. — 2007. — № 3. — С. 32-38.

17 Интродукция растений природной флоры Казахстана. - Алма-Ата: Наука, 1984. — 115 с.

18 Куприянов А.Н. Интродукция растений / А.Н. Куприянов. - Кемерово: Кузбассвузиздат, 2004. — 94 с.

19 Максутова П.А. Физическая география Карагандинской области / П.А. Максутова, Ш.Е. Дюсекеева, А.О. Кулмаганбетова. - Караганда, 2005. - 59 с.

20 Ишмуратова М.Ю. Оценка успешности интродукции травянистых эфирно-масличных растений в условиях города Караганды / М.Ю. Ишмуратова, С.У. Тлеукенова, М.К. Бутумбаева // От растения до лекарственного препарата: сб. тр. Междунар. науч. конф. - М., 2020. - С. 17-24.

\section{М.К. Бутумбаева, М.М. Силантьева}

\section{Қарағанды және Жезқазған қалалары жағдайындағы Lamiaceae тұқымдас өсімдіктер интродукциясының табыстылығын бағалау}

\footnotetext{
Өсімдіктерді интродукциялаудың табыстылығын бағалау шаруашылық тұрғыдан алғанда жекелеген таксондарды өнеркәсіптік өсіру мүмкіндігін айқындаудың маңызды кезеңі болып табылады. Интродукцияның табыстылығы бірқатар көрсеткіштерді бағалау негізінде көпжылдық бақылаулар негізінде бағаланады. Зерттеудің мақсаты - Қарағанды және Жезқазған қалалары жағдайында Lamiaceae тұқымдасының түрлерін интродукциялаудың табыстылығына талдау жүргізу. Мақалада Қарағанды (Акад. Е.А. Бөкетов атындағы Қарағанды университеті) және Жезқазған (Жезқазған ботаникалық бағы) қалаларының аумағындағы Lamiaceae тұқымдас өсімдіктер интродукциясының табыстылығын бағалау қорытындылары келтірілген. Қарағанды қаласы бойынша 13 туыстың 20 түрі, Жезқазған қаласы бойынша 9 туыстың 14 түрі талданды. Өнеркәсіптік өсіру үшін өсімдіктерді
} 
ұсынуға мүмкіндік беретін перспективалық топтар айқындалды. Қарағанды қаласының жағдайында жоғары перспективалы топтарға 6 түрі, перспективалыға - 4 түрі, аз перспективалыға - 8 түрі, перспективалы емеске - 2 түрі жатқызылған. Жезқазған қаласында жоғары перспективалыға 2 түрі, перспективалыға - 3 түрі, аз перспективалыға - 4 түрі, перспективалы емеске - 5 түрі жатқызылған. Қарағанды және Жезқазған қалалары жағдайында өсіруге жарамды өсімдіктер анықталды. Алынған нәтижелер тамақ, хош иіс және фармацевтика өнеркәсібі үшін шикізат алу үшін пайдаланылуы мүмкін.

Кілт сөздер: интродукцияның табыстылығы, Lamiaceae, Қарағанды, Жезқазған тұқымдасы, бағалау балдары, өнеркәсіптік өсіру мүмкіндігі.

\title{
М.К. Бутумбаева, М.М. Силантьева \\ Оценка успешности интродукции растений семейства Lamiaceae в условиях городов Караганды и Жезказгана
}

\begin{abstract}
Оценка успешности интродукции растений является важным этапом определения возможности промышленного выращивания отдельных таксонов с хозяйственной точки зрения. Успешность интродукции оценивалась в ходе многолетних наблюдений на основе оценки ряда показателей. Цель настоящего исследования - провести анализ успешности интродукции видов из семейства Lamiaceae в условиях городов Караганды и Жезказгана. В статье приведены итоги оценки успешности интродукции растений семейства Lamiaceae на территории городов Караганды (Карагандинский университет им. акад. Е.А. Букетова) и Жезказгана (Жезказганский ботанический сад). По Караганде были проанализированы 20 видов из 13 родов, по Жезказгану - 14 видов из 9 родов. Определены группы перспективности, которые позволяют рекомендовать растения для промышленного выращивания. В условиях города Караганды к группе высокоперспективных отнесены 6 видов, перспективных - 4, малоперспективных - 8, неперспективных - 2 вида. В городе Жезказгане к высокоперспективным отнесены 2 вида, к перспективным - 3, малоперспективным - 4, неперспективным - 5 видов. Выявлены растения, пригодные для выращивания в условиях гг. Караганды и Жезказгана. Полученные результаты могут быть использованы при получении сырья для пищевой, ароматической и фармацевтической промышленности.
\end{abstract}

Ключевые слова: успешность интродукции, семейство Lamiaceae, Караганда, Жезказган, оценочные баллы, возможность промышленного выращивания.

\section{References}

1 Karpun, Yu.N. (2004). Osnovy introduktsii rastenii [Base of plant introduction]. Hortus botanicus, 2, 17-32 [in Russian].

2 Krokhmal', I. (2016). Kontseptsiia prohnoza uspeshnosti introduktsii travianistykh mnoholetnikov v stepnuiu zonu Ukrainy [Concept of forecast of success of introduction of herbaceous perennials into the steppe zone of Ukraine]. Vestnik Kievskoho natsionalnoho universiteta imeni T. Shevchenko - Bulletin of T. Shevchenko Kiev national university, 1(71), 66-77 [in Russian].

3 Abysheva, L.N., Belenovskaya, L.M., \& Bobyleva, N.S. (2001). Dikorastushchie poleznye rasteniia Rossii [Wild useful plants of Russia]. Saint Petersburg [in Russian].

4 Myadelenec, M.A. (2008). Hubotsvetnye Khakasii: vidovoi sostav, ekolohiia i perspektivy ispolzovaniia [Lamiaceae of Khakassia: species composition, ecology and prospects for use]. Extended abstract of Candidate's thesis. Novosibirsk [in Russian].

5 Grudzinskaya, L.N., Gemedzhieva, N.G., Nelina, N.V., \& Karzhaubekova, Zh.Zh. (2014). Annotirovannyi spisok lekarstvennykh rastenii Kazakhstana [Annotated list of medicinal plants of Kazakhstan]. Almaty [in Russian].

6 Logvinenko, L.A., Hlypenko, L.A., \& Marko, N.V. (2016). Aromaticheskie rasteniia semeistva Lamiaceae dlia fitoterapii [Aromatic plants of family Lamiaceae for phyto-therapy]. Farmatsiia i farmakolohiia - Pharmacia and pharmacology, 4(4), 34-47. https://doi.org/10.19163/2307-9266-2016-4-4-34-47 [in Russian].

7 Khoury, M., Stien, D., Eparvier, V., Ouaini, N. \& El Beyrouthy, M. (2016). Report on the Medicinal Use of Eleven Lamiaceae Species in Lebanon and Rationalization of Their Antimicrobial Potential by Examination of the Chemical Composition and Antimicrobial Activity of Their Essential Oils. Hindawi, Article ID 2547169. https://doi.org/10.1155/2016/2547169

8 Blank, D.E., Alves, G.H., Nascente, P. Da S., Freitag, R.A., \& Cleff, M.B. (2020). Chemistry and Environment Bioactive Compounds and Antifungal Activities of Extracts of Lamiaceae Species. Journal of Agricultural Chemistry and Environment, 9, 8596. https://doi.org/10.4236/jacen.2020.93008

9 Carović-Stanko, K. Grdiša, M., Pintar, J., Bedeković, D., Ćustić, M.H., \& Satovic, Z. (2016). Medicinal Plants of the Family Lamiaceae as Functional Foods - a Review. Czech J. Food Sci., 34(5), 377-390. https://doi.org/10.17221/504/2015-CJFS

10 Zvezdina, E.V., Daironas, Zh.V., Bochkareva, I.I., Zilfikarov, I.N., Babaeva, E.Yu., \& Ferubko, E.V., et al. (2020). Predstaviteli semeistva Lamiaceae Lindl. kak istochniki lekarstvennoho rastitelnoho syria dlia polucheniia neirotropnykh sredstv (obzor) [Representatives of the Lamiaceae Lindl family as sources of medicinal plant raw materials for the production of neurotropic agents (overview)]. Farmatsiia i farmakolohiia - Pharmacia and pharmacology, 8(1), 4-28 [in Russian]. 
11 Rafiyeva, S. (2019). Essential oil features of some species of Lamiaceae Lindl. Family. Black sea scientific journal of academic research, 46(3), 30-33.

12 Flora Kazakstana [Flora of Kazakhstan]. (1964). (Vol. 7). Alma-Ata: Publ. of Academy of Science of KazSSR [in Russian].

13 Ishmuratova, M.Yu., Butumbaeva, M.K., \& Zholdybaeva, K.B. (2020). Izuchenie rasprostraneniia rastenii semeistva Hubotsvetnye na territorii Karahandinskoi oblasti [Study of the distribution of plants of the Lamiaceae family in the Karaganda region]. Proceeding from Methodology, theory and practice of modern biology: $V$ Mezhdunarodnaia nauchno-prakticheskaia konferentsiia - International scientific-practical conference. (p. 171-176). Kostanai [in Russian].

14 Akhmetalimova, A.M., Orazbayeva, P.Z., Ishmuratova, M.Yu., Ivasenko, S.A., \& Glowniak, K. (2017). Study of raw material resources of Thymus marschallianus at the territory of the Central Kazakhstan. Bulletin of the Karaganda University. Biology, Medicine. Geography Series, 4, 8-13.

15 Butumbaeva, M.K., Ishmuratova, M.Yu., \& Tleukenova, S.U. (2020). Otsenka hoziaistvennykh svoistv vidov iz semeistva Hubotsvetnye flory Karahandinskoi oblasti [Assessment of the economic properties of species from the family Lamiaceae flora of the Karaganda region]. Proceedings from Actual problems of science in sphere of natural and agricultural sciences: Mezhdunarodnaia nauchno-prakticheskaia konferentsiia - International scientific-practical conference. (Vol. 1, p. 74-77). Petropavlovsk [in Russian].

16 Ishmuratova, M.Yu. (2007). Introduktsiia Ziziphora clinopodioides Lam. v usloviiakh Tsentralnoho Kazakhstana [Introduction of Ziziphora clinopodioides Lam. in the conditions of the Central Kazakhstan]. Vestnik Karahandinskoho universiteta. Seriia Biolohiia. Meditsina. Heohrafiia - Bulletin of the Karaganda University. Biology. Medicine. Geography series, 3, 32-38 [in Russian].

17 Introduktsiia rastenii prirodnoi flory Kazakhstana [Introduction of natural flora plants of Kazakhstan]. (1984). Alma-Ata: Nauka [in Russian].

18 Kupriyanov, A.N. (2004). Introduktsiia rastenii [Plant introduction]. Kemerovo: Kuzbassizdat [in Russian].

19 Maksutova, P.A., Dyusekeeva, Sh.E. \& Kulmaganbetova, A.O. (2005). Fizicheskaia heohrafiia Karahandinskoi oblasti [Physical geography of Karaganda region]. Karaganda [in Russian].

20 Ishmuratova, M.Yu., Tleukenova, S.U. \& Butumbaeva, M.K. (2020). Otsenka uspeshnosti introduktsii travianistykh efirnomaslichnykh rastenii v usloviiakh horoda Karahandy [Evaluation of the success of the introduction of herbaceous essential-oilseeds in the conditions of the city of Karaganda]. Proceedings from From plant till medicinal preparation. Mezhdunsrodnaia nauchnaia konferentsiia - international scientific conference. Moscow [in Russian]. 